\title{
ВПЛИВ РЕАКЦЙННОГО ПОРОШКУ НА МІЦНІСТЬ ПОРОШКОВОГО БЕТОНУ
}

\section{INFLUENCE OF REACTION POWDER ON THE POPULAR CONCRETE DENSITY}

Шишкіна О. О., к. т. н., доцент., Шишкін О. О., д. т. н., професор. (Криворізький національний університет)

Shishkina A.A. Cand. tech Sciences, Associate Professor, Shishkin A.A. doc. Technical sciences, prof (Kryvyi Rih National University, Kryvyi Rih)

Наведено результати досліджень впливу реакційних порошків в присутності поверхнево-активної речовини, яка утворюс міцели, на величину міцності порошкового бетону i швидкість їі формування. Доведено, шо колоїдна поверхнево-активна речовина збільшує вплив реакційного порошку на міцність бетону.

It is determined that the active components of modern concrete are active mineral fillers, such as microsilica, meta-kaolin, ash-bearing or compositions from them, as well as superplasticizers. The optimal combination of these additive modifiers allows you to control the rheological properties of concrete mixtures and to modify the structure of the cement stone in such a way as to provide concrete properties that provide high operational reliability of structures. However, they have certain disadvantages that hamper their widespread use. The purpose of the research is to determine the effect of reaction powders applied simultaneously with colloidal surfactant, on the strength of powdered concrete and the rate of its formation. As a result of the experiments, it was established that the compressive strength of concrete resulting from the hydration of the dispersed system "Portland cement colloidal surfactant - reaction powder", when used as a reactive powder of melted river sand ash-removal TPP, fine fraction of waste of iron enrichment Ores and blast granular slag above the strength of concrete obtained on the basis of impregnated Portland cement. Thus, the presence in the dispersion of a colloidal surfactant provides increased compressive strength of the resulting concrete. The speed of the set of strength at the compression of concrete, obtained as a result of solidification of the dispersed system, "Portland cement - colloidal surfactant - reaction powder" depends on the type of applied reaction powder. So the highest speed of the set of strength and its finite value are the concrete containing the blend granular slag as a reaction powder. The research and their results have shown that the use of colloidal surfactant leads 
to an increase in the efficiency of the use of mineral powders obtained, in particular, from waste enrichment of iron ores and blast furnace granulated slag in reactive powder concrete. The most effective reactive powder, which is expedient to use simultaneously with the colloidal surfactant, is blast furnace granulated slag. This means that the use of colloidal surfactant is more effective for the modification of concretes based on slag-portland cement than for concrete in Portland cement.

Ключові слова: порошок, бетон, поверхнево-активні речовини, міцність. powder, concrete, surface-active substances, strength

\section{Вступ.}

Обов'язковими компонентами сучасного функціонального бетону $\epsilon$ активні тонкодисперсні мінеральні наповнювачі (наприклад, мікрокремнезем, метакаолін, зола-винесення або композиції з них) [1,2] і високоефективні суперпластифікатори. Оптимальне поєднання зазначених добавокмодифікаторів дозволяє управляти реологічними властивостями бетонних сумішей і модифікувати структуру цементного каменю на мікрорівні так, щоб надати бетону властивості, які забезпечують високу експлуатаційну надійність конструкцій $[3,4]$. Отримані властивості бетонів - це результат складних колоїдно-хімічних і фізичних процесів, що впливають на фазовий склад, пористість і міцність цементного каменю [5]. Для таких модифікованих бетонів характерні висока i надвисока міцність, низька проникність і екзотермія, підвищена корозійна стійкість і довговічність, поліпшені деформаційні характеристики. Важливо відзначити, що зазначені властивості досягаються із застосуванням високорухливих i самоущільнюючихся сумішей зі зниженими витратами цементу [6-8].

Аналіз останніх досліджень.

Найбільш широко в даний час в якості добавок-модифікаторів застосовуються мікрокремнезем [9] і метакаолін [10-12]. Однак вони мають певні недоліки, які стримують їх широке застосування. До таких недоліків слід віднести для мікрокремнезему те, що він є відходом виробництва, а, отже, не має стабільність властивостей. Для метакаоліну недоліком $є$ його висока вартість внаслідок досить високих енерговитрат на його приготування. На підставі викладеного, а також результатів досліджень в області міцелярного каталізу реакцій синтезу гідросилікатів кальцію [13], була визначена мета досліджень, результати яких викладені в даній роботі.

Постановка мети і задач досліджень. Метою досліджень $є$ визначення впливу реакційних порошків, застосованих одночасно із колоїдною поверхнево-активною речовиною (ПАР), на величину міцності порошкового бетону і швидкість ії формування. Відповідно до мети, задачами досліджень $\epsilon$ визначення залежності міцності бетону від кількості реакційного порошку, як 
за наявністю колоїдної ПАР, так і без неї; визначити вплив колоїдної ПАР на ефективність реакційного порошку стосовно підвищення міцності бетону.

Матеріали та методика досліджень. Для виготовлення бетону використовували портландцемент M400 ВАТ «Хайдельберг цемент Кривий Ріг» (Україна). Як дрібний заповнювач - відходи збагачення залізних руд Новокриворізького гірничо-збагачувального комплексу ПАТ «Арселор Міттал Кривий Ріг», які мають максимальний розмір часток 0,63 мм. Як міцелоутворююча ПАР (МПАР) - олеат натрію (Simagchem Согр., Китай). Як реакційні порошки використовували мелений річковий пісок, золу винесення TEC, тонкозернисту фракцію відходів збагачення залізних руд та мелений до питомої поверхні $300 \mathrm{~m}^{2} /$ кг доменний гранульований шлак.

Компоненти бетонної суміші дозували в необхідних, згідно 3 планом експерименту, кількостях, перемішували лабораторному змішувачі протягом 2 хвилин. Отримана суміш містилася за допомогою віброущільнення в металеву форму, яка має розмір сторін 16 х 4 х 4 см. Відформовані таким чином зразки бетону тверднули протягом 28 діб при вологості навколишнього середовища $70 \pm 10 \%$ і температурі навколишнього повітря $293 \pm 2 \mathrm{~K}$.

\section{Результати досліджень.}

Міцність при стиску бетону, отриманого в результаті гідратації дисперсної системи «портландцемент - комплексна МПАР - реакційний порошок», при використанні в якості реакційного порошку меленого річкового піску в кількості $15 \ldots 18 \%$ від маси дисперсної фази системи (рис.1), 20...30\% золи-виносу ТЕС (рис. 2) і $10 \ldots 30 \%$ тонкодисперсної фракції відходів збагачення залізних руд (рис.3) та доменного гранульованого шлаку (рис. 4) вище міцності бетону, отриманого на основі бездобавочного портландцементу.

Таким чином, наявність в дисперсної системі комплексної ПАР забезпечує підвищення міцності при стиску одержуваного бетону.

Швидкість набору міцності при стиску бетону, отриманого в наслідок твердіння дисперсної системи «портландцемент - комплексна МПАР реакційний порошок» залежить від застосованого реакційного порошку. Так найбільшою швидкістю набору міцності і її кінцевою величиною володіють бетони, що містять в якості реакційного порошку доменний гранульований шлак (рис.5). 


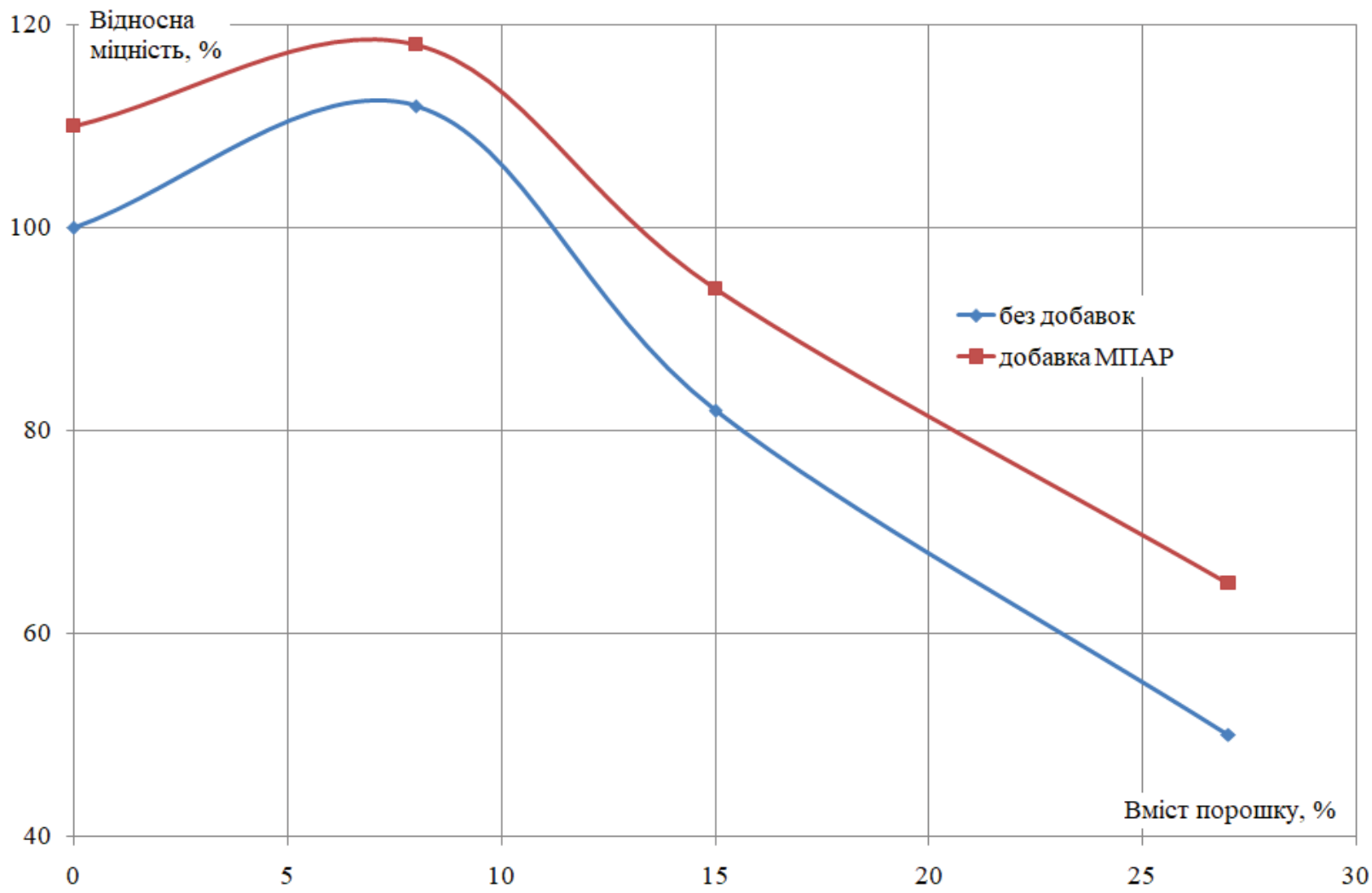

Рис 1 Вплив вмісту меленого річкового піску на міцність при стиску бетону, отриманого на основі дисперсної системи «портландцемент - комплексна МПАР реакційний порошок»

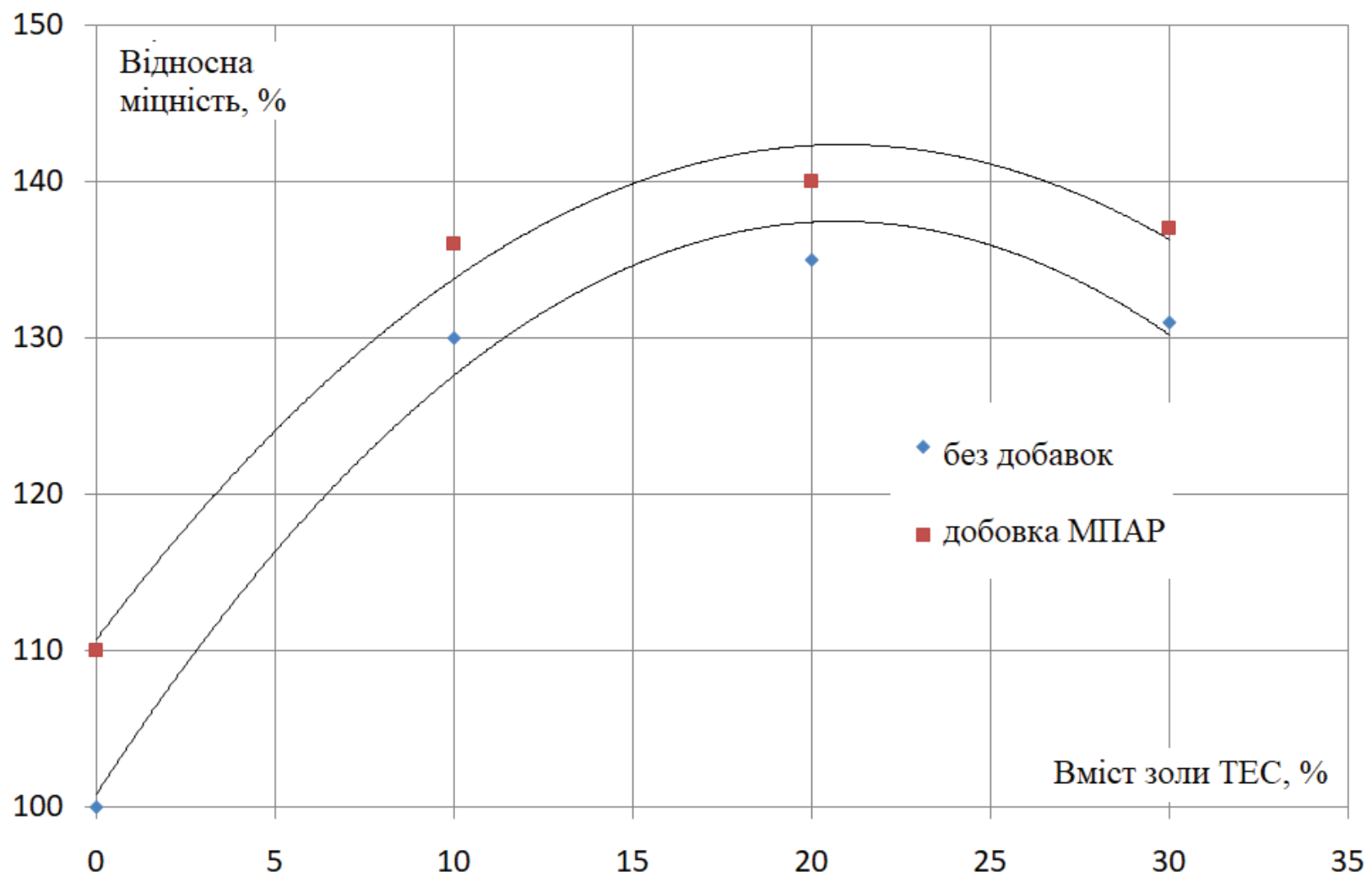

Рис. 2 Вплив вмісту золи-виносу ТЕС на міцність при стиску бетону, отриманого на основі дисперсної системи «портландцемент - комплексна МПАР - реакційний порошок» 


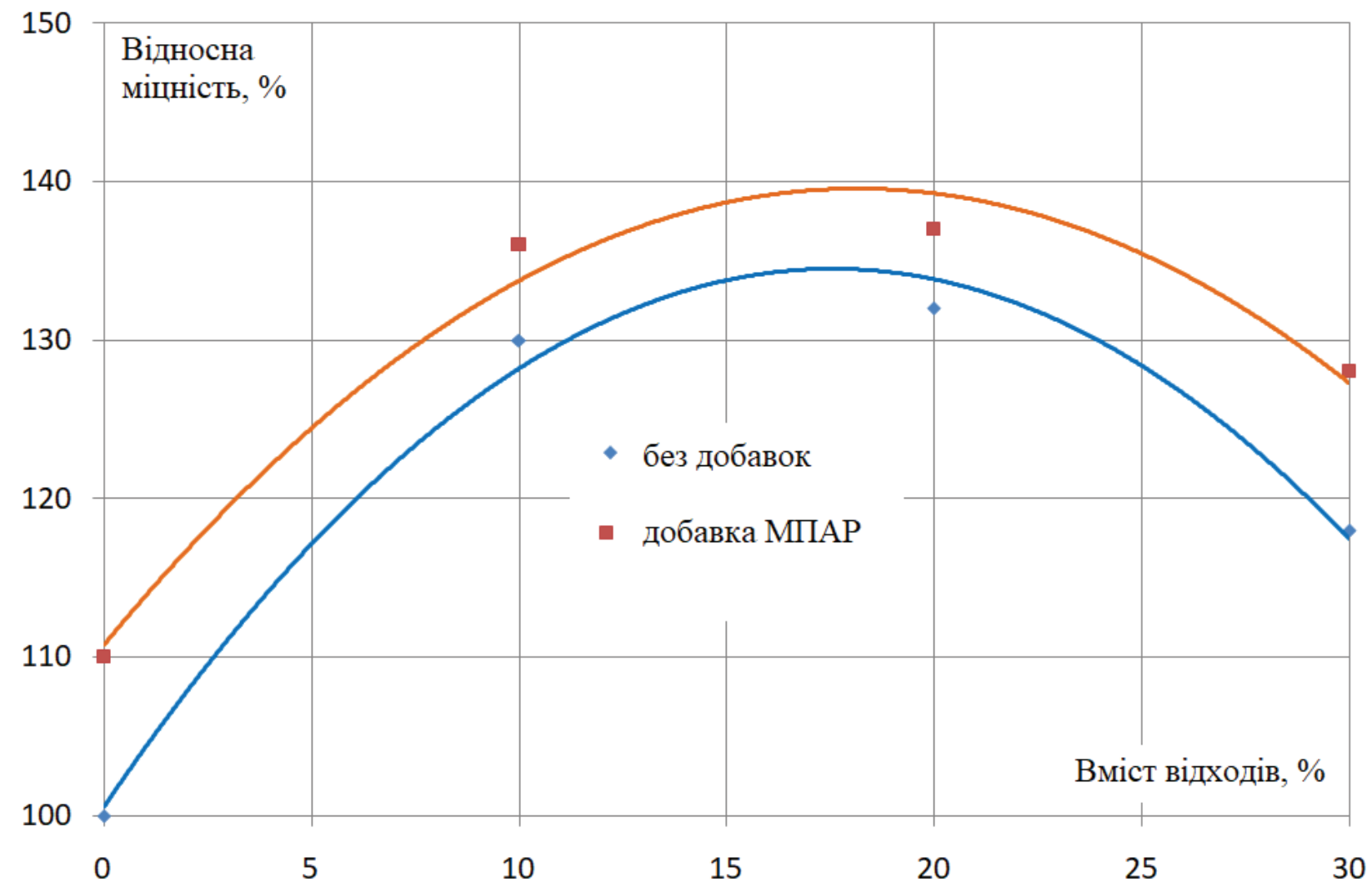

Рис. 3 Вплив вмісту відходів збагачення залізних руд на міцність при стиску бетону, отриманого на основі дисперсної системи «портландцемент - комплексна МПАР - реакційний порошок»

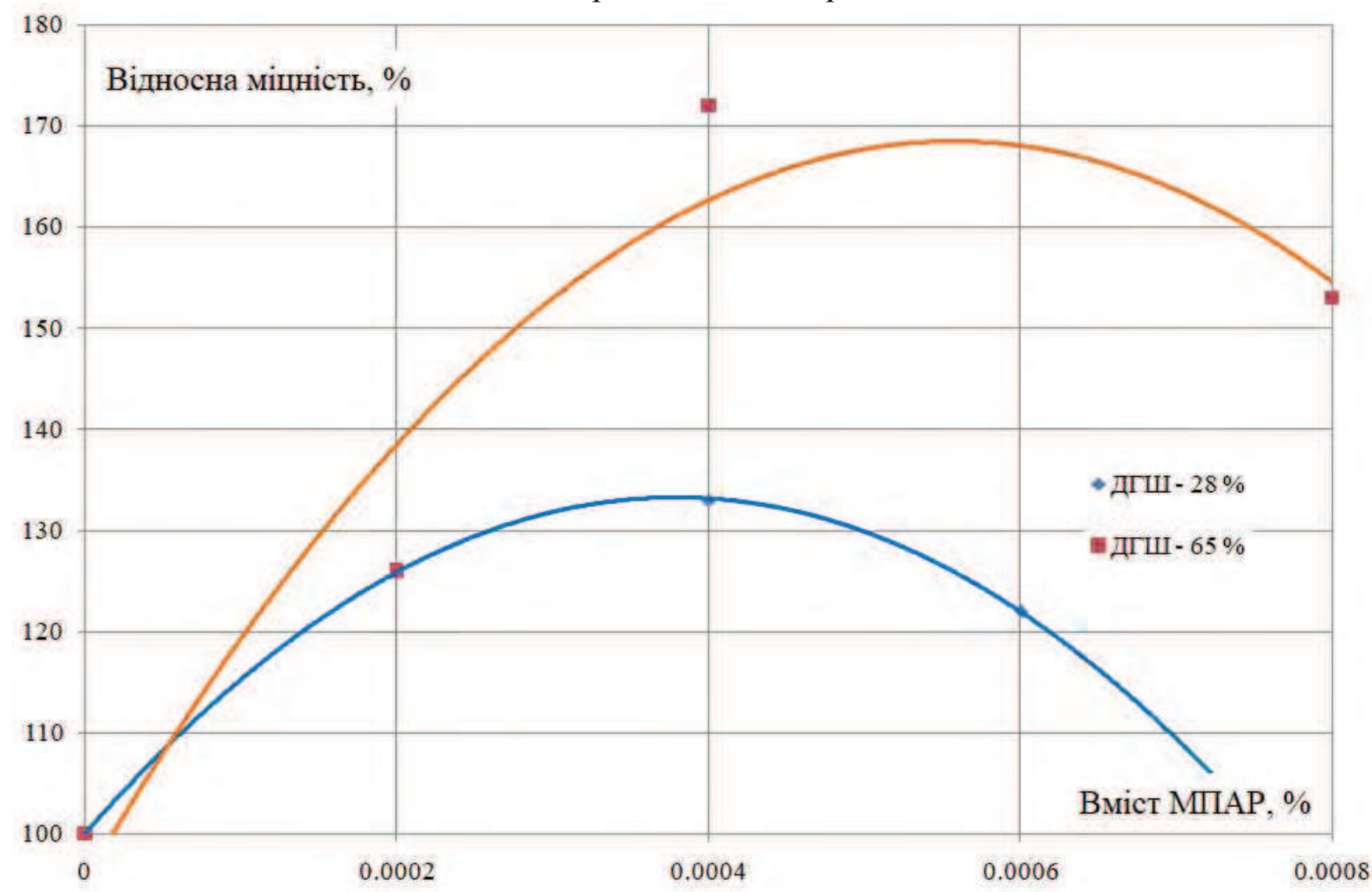

Рис. 4 Вплив вмісту МПАР на міцність при стиску бетону, отриманого на основі дисперсної системи «портландцемент - комплексна МПАР - реакційний порошок» (ДГШ - доменний гранульований шлак) 


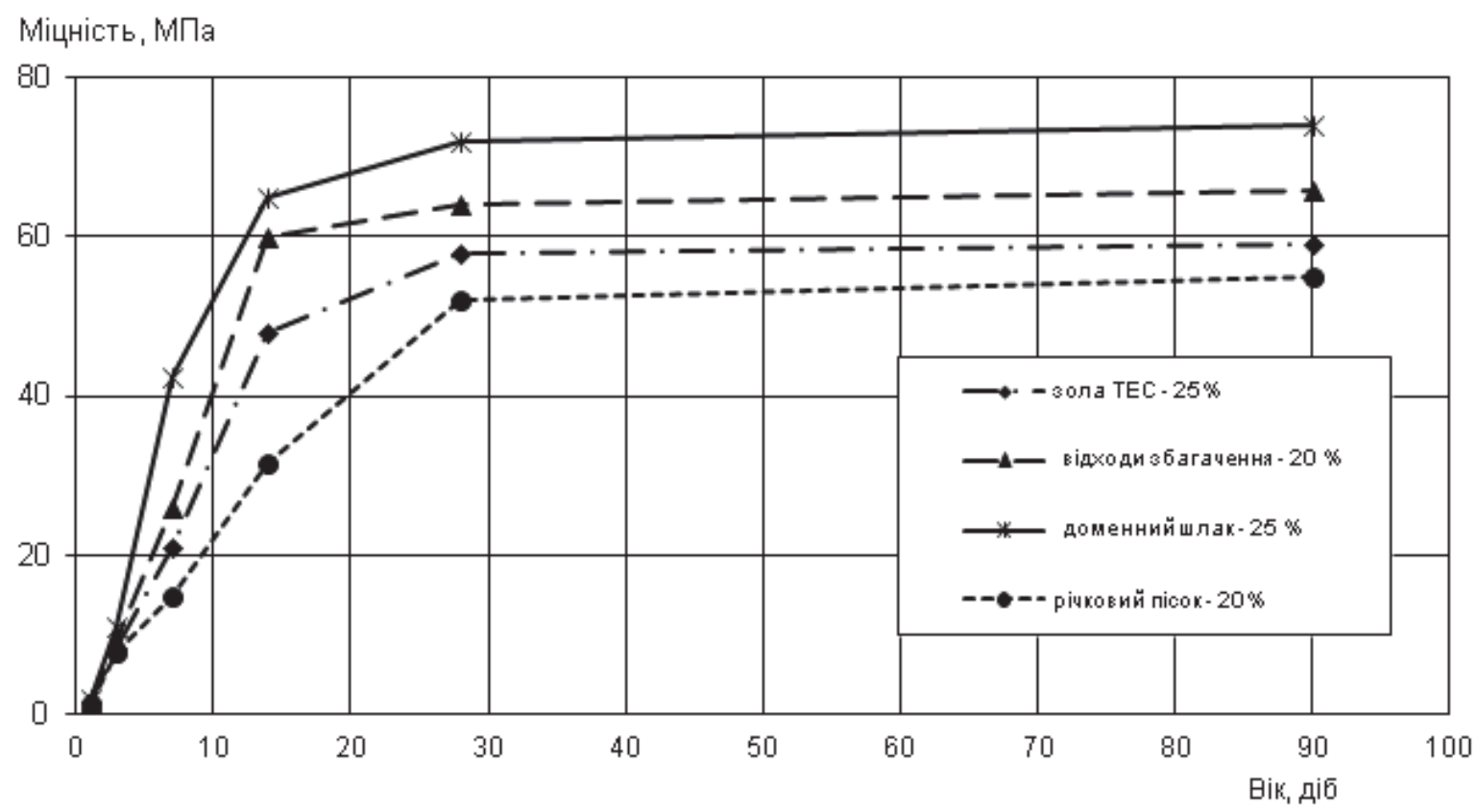

Рис. 5 Зміна в часі міцності при стисненні бетону з В / Ц = 0,35.

Таким чином, не тільки комплексна МПАР, а й реакційний порошок забезпечує збільшення швидкості набору міцності бетоном.

Аналіз результатів виконаних досліджень, показав наявність оптимуму вмісту в досліджуваній системі реакційного порошку, величина якого залежить від виду останнього. Порівняльний аналіз впливу означених видів реакційних порошків, застосованих при визначенні міцності бетонів, одержуваних на основі досліджуваної системи (рис. 6) показав, що використання в якості реакційного порошку доменного гранульованого шлаку забезпечує найбільший ефект підвищення міцності бетону в порівнянні з іншими реакційними порошками.

\section{Висновки.}

Виконанні дослідження та їх результати показали, що застосування колоїдної поверхнево-активної речовини призводить до підвищення ефективності застосування мінеральних порошків, отриманих, зокрема, із відходів збагачення залізних руд та доменного гранульованого шлаку в реакційно-порошкових бетонах. Найбільш ефективним реакційним порошком, який доцільно використовувати одночасно із МПАР, $є$ доменний гранульований шлак. Це означає, що застосування МПАР більш ефективно для модифікації бетонів на основі шлакопортландцементу ніж для бетонів на портландцементі. 


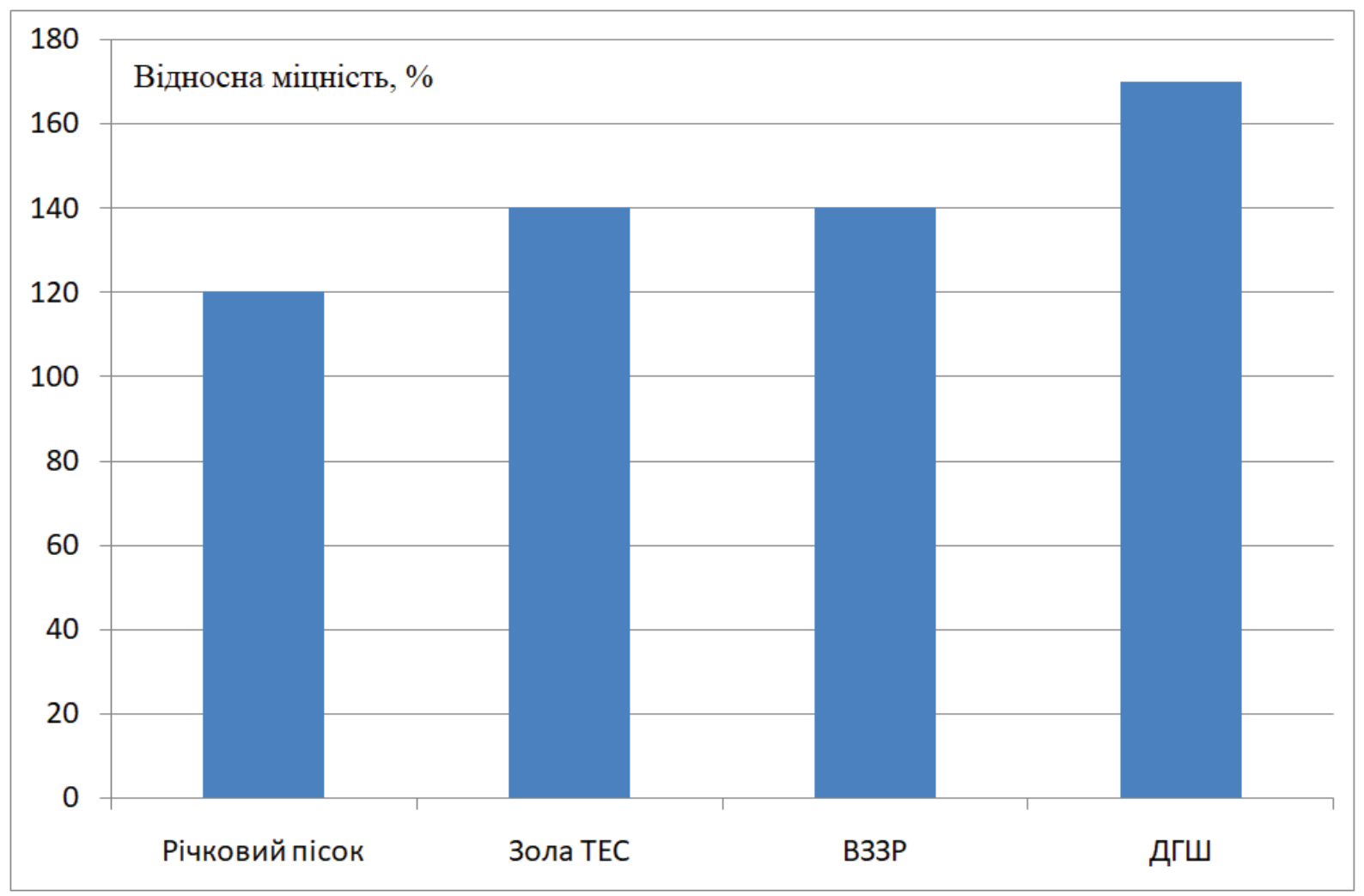

Рис. 6 Порівняння ефективності реакційних порошків

(В333 - відходи збагачення залізних руд, ДГШ - доменний гранульований шлак)

1. Каприелов С.С., Кардумян Г.С. Новые модифицированные бетоны в современных сооружениях // Бетон и железобетон. 2011. 2. С. 78-82.

2. Каприелов С. С., Шейнфельд А. В., Кардумян Г.С. Новые модифицированные бетоны, 2010. $-258 \mathrm{c}$.

3. Фролов А.В., Чумадова Л.И., Черкашин А.В., Акимов Л.И. Экономичность использования и влияние наноразмерных частиц на свойства легких высокопрочных бетонов. //Строительство уникальных зданий и сооружений. 2014. 19. С. 51-61.

4. Толстой А.Д., Лесовик В.С., Загороднюк Ј.Х., Ковалева И.А. Порошковые бетоны с применением техногенного сырья // Вестник МГСУ. 2015. 11. С. 101-109

5. Сопов В.П., Ткачук А.Л. Влияние минеральных добавок на структурообразование цементного камня // Науковий вісник будівництва. 2011. 66. С. 250-254.

6. Мороз М.Н., Калашников В.И., Худяков В.А., Василик П.Г. Водостойкий мелкозернистый бетон, гидрофобизированный наночастицами стеарата кальция // Строительные материалы. 2009. 8. С. 55-59.

7. Номоев А.В., Лыгденов В.Ц., Урханова Л.А., Лхасаранов С.А. Мелкозернистый цементный бетон с нанодисперсным модифікатором // Нанотехнологии в строительстве: научный интернет-журнал. 2010. 4. С. 42-52.

8. Христофоров А.И., Христофорова И.А., Кузьмин Д.И. Мелкозернистый бетон, модифицированный органическими соединениями $\mathrm{Na}+/ /$ Строительство и реконструкция. 2011. 2. С. 104-109.

9. Барабаш И.В., Ксьоншкевич Л.М., Крантовська О.М. Високоміцні бетони на механоактивованому в’яжучому // Збірник наукових праць УкрДАЗТ. 2014.149. С. 130-136. 
10. Морозов Н.М., БоровскихИ.В. Влияние метакаолина на свойства цементных систем // Известия КГАСУ. 2015. 3(33) . 127-132.

11. Краснобаева С.А., Медведева И.Н., Брыков А.С., Стафеева 3.В. Свойства материалов на основе портландцемента с добавкой метакаолина МКЖЛ // Цемент и его применение. 2015. С. 50-55.

12. Клёсова А.И., Голубева О.А. Влияние комплексных метакаолиновых добавок на свойства цементного камня // Проблемы геологии и освоения недр. 2014. С. 672673.

13. Шишкіна О.О., Шишкін О.О. Дослідження впливу нанокаталізу на формування міцності реакційного порошкового бетону // Восточно-европейский журнал передовых технологий. 2016. 1/6 (79). С. 55-60.

1. Kaprielov S.S., Kardumyan G.S. Novye modificirovannye betony v sovremennyh sooruzheniyah // Beton i zhelezobeton. 2011. 2. S. 78-82. 2. Kaprielov S. S., Shejnfeld A. V., Kardumyan G.S. Novye modificirovannye betony, 2010. - 258 s.

3. Frolov A.V., Chumadova L.I., Cherkashin A.V., Akimov L.I. Ekonomichnost ispolzovaniya i vliyanie nanorazmernyh chastic na svojstva legkih vysokoprochnyh betonov. //Stroitelstvo unikalnyh zdanij i sooruzhenij. 2014. 19. C. 51-61.

4. Tolstoj A.D., Lesovik B.C., Zagorodnyuk JI.X., Kovaleva I.A. Poroshkovye betony s primeneniem tehnogennogo syrya // Vestnik MGSU. 2015. 11. S. 101-109.

5. Sopov V.P., Tkachuk A.L. Vliyanie mineralnyh dobavok na strukturoobrazovanie cementnogo kamnya // Naukovij visnik budivnictva. 2011. 66. S. 250-254.

6. Moroz M.N., Kalashnikov V.I., Hudyakov V.A., Vasilik P.G. Vodostojkij melkozernistyj beton, gidrofobizirovannyj nanochasticami stearata kalciya // Stroitelnye materialy. 2009. 8. S. 55-59.

7. Nomoev A.V., Lygdenov V.C., Urhanova L.A., Lhasaranov S.A. Melkozernistyj cementnyj beton $\mathrm{s}$ nanodispersnym modifikatorom // Nanotehnologii $\mathrm{v}$ stroitelstve: nauchnyj internet-zhurnal. 2010. 4. S. 42-52.

8. Hristoforov A.I., Hristoforova I.A., Kuzmin D.I. Melkozernistyj beton, modificirovannyj organicheskimi soedineniyami Na+ // Stroitelstvo i rekonstrukciya. 2011. 2. S. 104-109.

9. Barabash I.V., Ksonshkevich L.M., Krantovska O.M. Visokomicni betoni na mehanoaktivovanomu v'yazhuchomu // Zbirnik naukovih prac UkrDAZT. 2014.149. S. $130-136$.

10. Morozov N.M., BorovskihI.V. Vliyanie metakaolina na svojstva cementnyh sistem // Izvestiya KGASU. 2015. 3(33) . 127-132.

11. Krasnobaeva S.A., Medvedeva I.N., Brykov A.S., Stafeeva Z.V. Svojstva materialov na osnove portlandcementa s dobavkoj metakaolina MKZhL // Cement i ego primenenie. 2015. S. 50-55.

12. Klyosova A.I., Golubeva O.A. Vliyanie kompleksnyh metakaolinovyh dobavok na svojstva cementnogo kamnya // Problemy geologii i osvoeniya nedr. 2014. S. 672-673.

13. Shishkina O.O., Shishkin O.O. Doslidzhennya vplivu nanokatalizu na formuvannya micnosti reakcijnogo poroshkovogo betonu // Vostochno-evropejskij zhurnal peredovyh tehnologij. 2016. 1/6 (79). S. 55-60. 